\title{
THE CORRELATION BETWEEN HUMAN RIGHTS AND HUMAN OBLIGATIONS (AN ANALYSIS OF ISLAMIC CRIMINAL LAW)
}

\author{
Hamzah Hasan ${ }^{1}$ \\ La Ode Ismail Ahmad ${ }^{2}$ \\ Alauddin State Islamic University of Makassar ${ }^{1,2}$ \\ hamzahhasan463@yahoo.com¹, laode.ismail@uin-alauddin.ac.id ${ }^{2}$
}

\begin{abstract}
This article will try to see how the correlation between Human Rights Obligations and Human Rights when viewed in the perspective of Islamic Criminal Law. The theme of Human Rights Obligations, by scientists and the world community, is not an issue that is considered as important as the issue of Human Rights. Even though the Human Rights Obligation is an important point of whether human rights are upright or not. The description of the relationship is in the concept of Islamic criminal law as summarized in al-Daruriyyat al-khamzah (religious preservation obligations, life obligations, obligations to preserve reason, obligations to preserve offspring and obligations to preserve property.
\end{abstract}

\section{Keywords: KAM-HAM-Islamic Criminal-Correlation}

\section{INTRODUCTION}

Human Rights has been a central issue in the global stage today. Every action people commited is always attributed to the Human Rights cause. It is because Human Right has neither limit to the countries' border line, politics, nor the law itself. Human Rights is a basic rights given to all human being ${ }^{1}$. Meriam Budihardjo explains that Human Rights is inherited to all human being eversince they were born ${ }^{2}$ so when it comes to someone breaking these rules, they could be charged or taken a progressive measure based on national or international law.

Unlike human rights, human obligations is under the spotlight of the international community. Human obligations is a fundamental point to the human rights stand off. This can be perceived if there is someone doing something that is in their rights but denying others' right, this is equal to a human rights abuse. The prophet Muhammad once asked by a Jew "If you cut the relationship with the Jews, would you potect my people?" the Prophet replied "Your blood is my blood, your protection is my protection. You are part of my soul. I shall fight your enemies and I shall make peace to whomever you choose to make". 3

The statement reiterated by the Prophet to the Jewish delegation in the Aqabah al-Kubra agreement came into real regarding his promise to protect the Jews. The rights of the Jews requested to the Prophet was served.

\footnotetext{
${ }^{1}$ Eko Hidayat, "Perlindungan Hak Asasi Manusia Dalam Negara Hukum Indonesia," Asas: Jurnal Hukum dan Ekonomi Islam, 2016.

${ }^{2}$ Meilanny Budiarti Santoso, "LGBT dalam Perspektif Hak Asasi Manusia," Share : Social Work Journal, 2016, https://doi.org/10.24198/share.v6i2.13206.

${ }^{3}$ Ahmad Sukardja, Piagam Madinah \& Undang-Undang Dasar NRI 1945 Kajian Perbandingan tentang Dasar Hidup Bersama dalam masyarakat yang Majemuk (Jakarta: Pena Grafika, 2012).
} 
Islam determines the worldly law and the hereafter. Breaking the law in the world will also lead to a trouble in the afterlife. Therefore, Muslim are obliged not only to follow the rules in the world, because it will impact their sake in the after life.

Alquran have much explained about this redemption, for example in albaqarah/2: 178, al-Maidah/5: 32-33. These verses explains about the law of world and heaven. Escaping the law of the world does not mean escaping from the law of the heaven, unless they admit a repentance to God (al-Maidah/5: 34)

Everyone has their own obligations, same as to their rights. These two are equivalent and works under the law. Therefore, according to the Islamic criminal law, human obligations is more important than that of the human rights.

To ensure the implementation of human rights and human obligations, one's country must abide to the law and order. It means that the state must also protect the human obligations of the people.

In this case, if implemented, people would be obliged to protect the people's right to exist. This will lead to the orderly life and comply to the sunnatullah. People has no right to obstruct others' rights, people has no right to hinder the people's right to exist. This article will try to explain the correlation between human rights and human obligations from the perspective of Islamic criminal law.

\section{LITERATURE REVIEW}

\section{a. Human rights}

(Hamilton, 1959, 1960; Maier et al., 1988; Depression and Scale, 2004; Stier et al., 2004; Prajarto, 2005; Trivedi et al., 2006; HAM, 2017)

According to Abu al-'Ala al-Maududi, human rights has two concepts. First, the rights of human or huquq al-insan al-dharuriyyah; second, the rights of God or huquq Allah. These two concepts are inseparable. These concept also distinguish between Islamic human rights and western human rights. In Islamic perspective, there are three kinds of human rights. Firstly, basic right (dharuriyyah). It is called basic rights when it is violated, the existence of people are threatened. Secondly, the secondary right (hajy). When this rights are violated, the elementary needs would loose. For example, when people lost their right to obtain food, their life would be threatened. Thirdly, the tertiary right (tahsiniyyah), this right comes after the primary and secondary rights.

Human rights is nature rights. ${ }^{4}$ The phrase human rights consisted of two words; human and right. In Arabic, the word right means al-huquq. Human has natural rights (al-huquq al-thabi'ah). the word al-huquq is derived from words haqqa,yahiqqu, haqqan in Arabic, means right, real, certain, fixed, and obliged. From here, we can understand that human rights is an integral part of every human being and no one is allowwed to violate those rights. On the other hand, one cannot do anything they desire to do without considering other people's right.

b. Human obligations

In Arabic, obligation means al-wajib ${ }^{5}$ obligation is a must and cannot be aborted.

\footnotetext{
4 Mohamad Hudaeri, "Islam dan Hak Asasi Manusia," ALQALAM, 2007, https://doi.org/10.32678/alqalam.v24i3.1664.

${ }^{5}$ Abd. Azis Dahlan, Ensiklopedi Hukum Islam, 6 ed. (Jakarta: Ichtiar Baru Van Hoeve, 1996).
} 
Accordingto the Constitution of The Republic of Indonesia No. 39 year 1999 about Human Rights Article 1 Section (2) Basic obligation is a set of obligation which are the fundamental of the Human Rights ${ }^{6}$ the rights come after the obligations.

From the explanation above, human rights and human obligations are related to each other. There are no human rights without human obligations.

\section{THE CORRELATION BETWEEN HUMAN RIGHTS AND HUMAN OBLIGATIONS}

Like two sides of the coin, human rights and human obligations are inseparable. The concept of human rights will only exist when people first fullfill their obligations. Human needs other human to interact in social life. To do so,a set of rules is created such as religious and social values, and public order. In the other words, the human rights will only present after the obligations is presented by other people.

Obligations is the key to deliver the rights in a matter of humanity. People who do not carry out their obligations are those who abandon their humanity. Thus, obligations is the starting point to the other subsequences.

In a state, the government and their people carrying out their sole obligations will create a harmony in the statehood. Putting obligations first does not mean abandoning our rights. On the contrary, the other people's rights is preserved. A responsible leader is a leader who preserve the rights of their people, and people who execute their obligations are the people who serves the rights of their leader ${ }^{7}$.

Individual rights is only given to the person himself or his ward. A state leader has no right to give amnesty to the perpetrator of Islamic law. However, some cases in which the law breaker has no ward, the leader of the state then take the position as a ward.

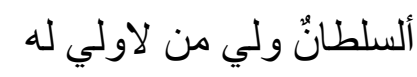

"A leader is a ward to whom without ward."

According to the Islamic criminal law, one who break the sharia law is the one who essentially commit a crime. This is known as jarimah Ijabiyyah or delicta. ${ }^{8}$ This crime includes plundering, adulttery, drinking alcohol, persecution, murder etc. Jarimah ijabiyyah means breaking the clear and obvious law.

Other criminals consiedered in Islamic criminal law is disobedience or refuse to follow the order of the sharia law such as do not pray, do not perform fasting, do not pay the alms giving (zakat). This crime is known as jarimah salabiyah or delicta ommisionis. Mostly, people violates the jarimah ijabiyyah. ${ }^{9}$ But jarimah positive can be negative. For example, a mother does not feed her child until they exhausted to death. In this case, this mother has conducted a premediated murder according to Imam Malik, Syafi'i, and Ahmad bin Hanbal. ${ }^{10}$ Imam Abu Yusuf and Muhammad bin Hasan, apprentices of Imam Abu Hanifah, said that it is catgorized as a premediated murder. The reason is that people

\footnotetext{
${ }^{6}$ Subandi Al-Marsudi, Pancasila dan UUD 1945 Dalam Paradigma Reformasi (Jakarta: Rajawali Press, 2000).

${ }^{7}$ H. A. Djazuli, Fiqh Siyasah, Implementasi Kemaslahatan Umat dalam rambu rambu Syariah, n.d.

${ }^{8}$ Abdul Qadir Audah, Al-Tasyrî’ al-Jināî al-Islāmî (Beirut: Muassasah al-Risālah, 1987).

${ }^{9}$ Audah.

${ }^{10}$ Audah.
} 
cannot survive without food and drink. Thus, preventing people for drinking and eating is an act of murder. ${ }^{11}$

The conclusion of the case above is that when someone can do something but choose not to do so regarded as a passive criminal perpetrator. The mother does not serve her obligation to feed the child when she is able to do so, but she takes the right to life from her own child. The child would have lived if the mothe paid for her obligations to her child, because the life of the child depends on it. al-Syatibi says there are five objetives in the Islamic law, they are protection of faith, life, reason, posterity, and protection of prosperity. These five objectives is called kulliyah al-khams or al-qawaid al-kulliyah. ${ }^{12}$

The five objectives of sharia used as a benchmark of the law is divided into three stages:

a. Daruriat, this is an onligation to protect five essential needs of the human being. Those are the protection of faith, life, reason, posterity, and protection of prosperity. If these five principal are failed to protect, the five objections would be at risk

b. Hajiyat, it is a non essential needs. This stage could evade people from hardship. The five objetives will not be ceased if this stage is not well protected, but the hardship will remain exist for the mukallaf.

c. Tahsiniyat. This stage is where the dignity is sought before the society and before the God (Mardani: 2013)

The above stages is also classified according to its scale of the requirement:

a. Protecting the faith (hifz al-din), is to perform all the primary commandments in religion in daruriyyat stage, such as five time prayer a day. Otherwise, the existence of the religion would be endangered.

b. Protecting the faith in the hajiyyat stage, is performing all the religious commands in order to prevent hardships, such as shortening the prayer (jamak and qasr) for traveler. The religion would not be threatened if this is not performed.

c. Protecting the faith in the tahsiniyat stage, is to obey the religion in order to keep the humanity prevail and to serve God, such as covering our aurat when or not in prayer, cleaning ourselves, clothes, and our places. If this is impossibly done, it will not threaten the religion, nor bothering the people themselves. ${ }^{13}$

Performing shalat (prayers) means prevailing the religion and the harmony between other beliefs. Likewise, the obligations to respect people who perorm prayers means that they have respected the right of other people to practice their faith.

Protecting life (hifz al-nafs) in the daruriyyat level is evading one self from lifethreatening actions such as killing or self-harming. Consuming food is one of the way to survive from dying. Islamic criminal law strongly prohibit murder or any other kind of life threatening actions and can be imposed to qisas. Qisas is a form of law to protect the right to life of the people, as explained in al-Baqarah/2: 179:

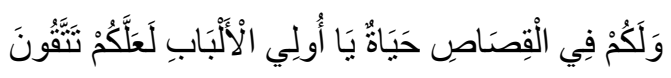

\footnotetext{
${ }^{11}$ Audah.

12 Mardani, Ușul Fiqh (Jakarta: Raja Grafindo Persada, 2013).

13 Mardani.
} 
Meaning:

"And there is for you in legal retribution [saving of] life, O you [people] of understanding, that you may become righteous."

The point of efrocing the qisas is that when the legal is imposed to the culprit, it means the right to life of the people has been withstood. More evidence from Quran about how important this law is, as it is explained in al-Maidah/5: 32

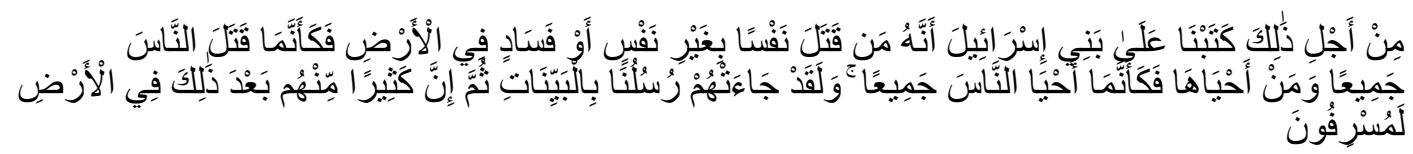

\section{Meaning:}

"Because of that, we decreed upon the children of Israel that whoever kills a soul unless for a soul or for corruption [done] in the land, it is as if he had slain mankind entirely. And whoever saves one, it is as if he had saved mankind entirely. And our messenger had certainly come to them with clear proofs. Then indeed many of them [even] after that, throughout the land, were transgressors."

The verse above explains that every single person on earth is essentially obliged to protect the life of all people regardless of their faith, tribes, or others. The verse tells that killing a person is similar to kill everybody else, and whoever preserves one's life is equal to protect the life of all else. However, the criminal law decides all the verdict juridically in the legal formal. ${ }^{14}$

P. A. F. Lamintang said that punishment is a form of ordeal given to the offender of the law by the the judge, and the decisions that is made is under the law of the criminal law. Those in which covered by the criminal law are as follows:
a. Life
b. Whole of human body
c. Dignity
d. Decency
e. Personal freedom
f. Wealthiness. ${ }^{15}$

Criminal law has a role to impose order to those who takes the rights of other people. The explanations above show that human rights and human obligations is indivisible. It can be seen when daruriyyat is performed. Conducting all those obligations means fulfilling the right of people to practice their faith. Protecting life is an assurance to protect people's right to live. Obligations to protect reason from destructive drugs and to punish who does so will allow others live their life free from delinquent. Obligations to protect posterity and avoid the sinful deed such as adultery. It is also related to the protection of the dignity. Protecting prosperity by avoiding stealing, fraud, corruption, and so on.

${ }^{14}$ J.M.Van Bemmelen, Hukum Pidana I Hukum Pidana Material Bagian Umum (Bandung: Bina Cipta, 1987).

${ }^{15}$ PA.F Lamintang, Hukum Penitensier Indonesia (Bandung: Armico, 1984). 


\section{CONCLUSION}

Human rights and human obligations is utterly indivisible and cannot go on one aspect over the other. Human rights can only endure if the human obligations stand still. The implementations painted in the concept of al-Daruriyyat al-Khamzah, the obligations to protect faith, life, reason, posterity, and protection of prosperity. Carrying the human obligations is fulfilling the human rights.

\section{REFERENCE}

Al-Marsudi, Subandi. Pancasila dan UUD 1945 Dalam Paradigma Reformasi. Jakarta: Rajawali Press, 2000.

Audah, Abdul Qadir. Al-Tasyrî̀ al-Jināî al-Islāmî. Beirut: Muassasah al-Risālah, 1987.

Bemmelen, J.M.Van. Hukum Pidana I Hukum Pidana Material Bagian Umum. Bandung: Bina Cipta, 1987.

Dahlan, Abd. Azis. Ensiklopedi Hukum Islam. 6 ed. Jakarta: Ichtiar Baru Van Hoeve, 1996.

Djazuli, H. A. Fiqh Siyasah, Implementasi Kemaslahatan Umat dalam rambu rambu Syariah, n.d.

Hidayat, Eko. "Perlindungan Hak Asasi Manusia Dalam Negara Hukum Indonesia." Asas: Jurnal Hukum dan Ekonomi Islam, 2016.

Hudaeri, Mohamad. "Islam dan Hak Asasi Manusia." ALQALAM, 2007. https://doi.org/10.32678/alqalam.v24i3.1664.

Lamintang, PA.F. Hukum Penitensier Indonesia. Bandung: Armico, 1984.

Mardani. Ușul Fiqh. Jakarta: Raja Grafindo Persada, 2013.

Santoso, Meilanny Budiarti. "LGBT dalam Perspektif Hak Asasi Manusia." Share: Social Work Journal, 2016. https://doi.org/10.24198/share.v6i2.13206.

Sukardja, Ahmad. Piagam Madinah \& Undang-Undang Dasar NRI 1945 Kajian Perbandingan tentang Dasar Hidup Bersama dalam masyarakat yang Majemuk. Jakarta: Pena Grafika, 2012. 